\title{
The Analysis of Potential 4A's Tourism Component in the Selasari Rural Tourism, Pangandaran, West Java
}

\author{
Tomy Andrianto, SST., MM.Par \\ Commerce Department, \\ Politeknik Negeri Bandung, \\ Bandung 40012, Indonesia \\ tomyandrianto@polban.ac.id
}

\author{
Dr. A Gima Sugiama, SE., MP \\ Commerce Department, \\ Politeknik Negeri Bandung, \\ Bandung 40012, Indonesia \\ gimasugiama@yahoo.com
}

\begin{abstract}
Santirah River as one of the main attraction in Selasari rural tourism had been famous by the viral marketing through the internet and social media in 2015. The local government of the Village claim that they have another amazing tourist attraction and already settled all of the 4A's (attraction, accessibility, amenities and ancillaries) tourism component in the area. By this it mean, the objective of this research is twofold, the first one to identify the 4 A's Tourism Component in Selasari Village, second one to analyze whether the development of tourist attraction are potential to be developed by the rural community of Selasari. The method of this research was descriptive qualitative based on exploratory study, which means that the data collected by qualitative and exploration method and then describe in descriptive. The data was gathered by observation and in-depth interview to head of the Village and the rural communities as a developer of the rural tourism area. A questionnaire and checklist were used to gather the data with judgment sampling technique guided. The results show that there are 3 type of potential tourist activities in Selasari, not only explore the natural activities but also cultural and special interest tourism. According to the data that collected, the other A's except attraction still needs to develop in the future especially the accessibility and amenities because these does not meet the tourism component standard such as bad road and out of standard Accommodation or Restaurant. In fact, it is slightly difficult to find these place because not enough sign board from another area in Pangandaran. The last A for Ancillary has been quite good but need additional effort, such as need support from the local government of Pangandaran, strict rules that could strengthen its presence of the natural especially the forest to keep the water in its places.
\end{abstract}

Keywords: 4A's Tourism Component, rural tourism, body rafting, cultural and special interest tourism.

\section{INTRODUCTION}

Tourism considered as one of the fastest growing Industries in the World (Esmailzade, 2013, Matiza and Olabanji, 2014, Sugiama, 2014b). One of the most important issues in tourism research nowadays is effective preservation and rational usage of existing environmental, climatic, health and recreational resort resources, and rural territories as rural tourist' destination (Lietaer and Meulenaere, 2003, Ivolga and Vasily, 2013). The rural tourism development is generally supposed to be raising economic viability of the village inhabitant, and such approach usually caters for pro-poor tourism or poverty reduction (Guo and others, 2014., Mutana, 2013., Sugiama, 2013).

Tourism development in rural tourism is contributing positively towards poverty alleviation, employment, incomegenerating, and has made an improvement on the tourist attractions, accessibility, amenities, and tourism ancillary (Karmilah, 2014., Sugiama, 2013). Rural tourism development can also guarantee an increase of tourists which will increase the income of local residents, new employment, increase the economy, and alleviate poverty in rural areas. However, the increasing number of tourist tend to destroy the exotic culture of its rural (Lietaer and Meulenaere, 2003, sugiama, 2013).

By this it means that local communities in tourist destination should aware develop rural tourism is not only depend on tourist attraction but also the other component nad the aspect of potentiality especially the culture impact. This study was conducted to identify the quality of the 4 A's Tourism Component in Selasari Rural Tourism; attraction, accessibility, amenity, Ancillary and to analyze whether the tourist attractions are potential to be developed in the future.

\section{LITERATUR REVIEW}

\section{A. Rural Tourism Development}

Rural tourism is the tourism development in rural areas, it covers all tourism activities that take place in rural areas that require travel services in the same places (Mrkša and Tamara, 2014., Sugiama, 2014c). World Tourism Organization state that rural tourism is tourism where rural culture is a key component of recreational tourist product (Dorobantu et al., 2012, p.4). According to Smith and Eadington, rural tourism is characterized by alternative tourism, sometimes referred to as "special interest tourism" or "responsible tourism". It is usually meant as alternative forms of tourism, which gives emphasis on the contact and understanding about inhabitants' way of living 
and the local natural environment (Dragulanescu and Maricica, 2012, p.198).

Rural tourism can be developed based on Natural and Cultural Conservation (NCC), which is the innovative way to combine tourism, NCC, generate income, and poverty reduction (Adamowicz, 2010., Guo and others, 2014., Sugiama, 2014c). All members of the local population must have the awareness, information, and opportunities to participate and choose from in order to make decisions about their livelihoods in the area of tourism development based on NCC principles and concepts (Adamowicz, 2010., Anand et al, 2012). This initiative and effort is the best choice of decision to protect areas, in the provision of benefits from protected areas, and a common means of providing such benefits is tourism development, economic, to support conservation, and it remains to be seen where it will take them in the long run of Tourism Activities (Anand et al, 2012., Walpole, 2001)

This figures below shows Integrated Rural Tourism Development Model (Sugiama, 2015) based on Quadro Helix (Government, local Communities, Business sector and academia). Here is the potential of tourism component that can be developed in the future from fourth (4) aspects, namely:
These Four components of tourism need to be developed in order to complete the tourist attraction facilities and support, as reflected in Figure 2,

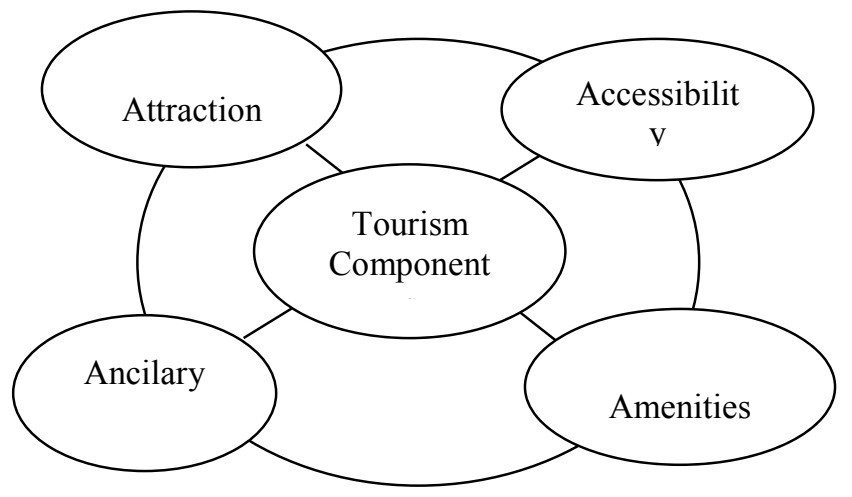

Figure 2. Tourism destination components (Sugiama, 2013)

This Tourism Components also namely as 4A's Tourism Component, which needs to consider as a basic component that tourist destination should have.

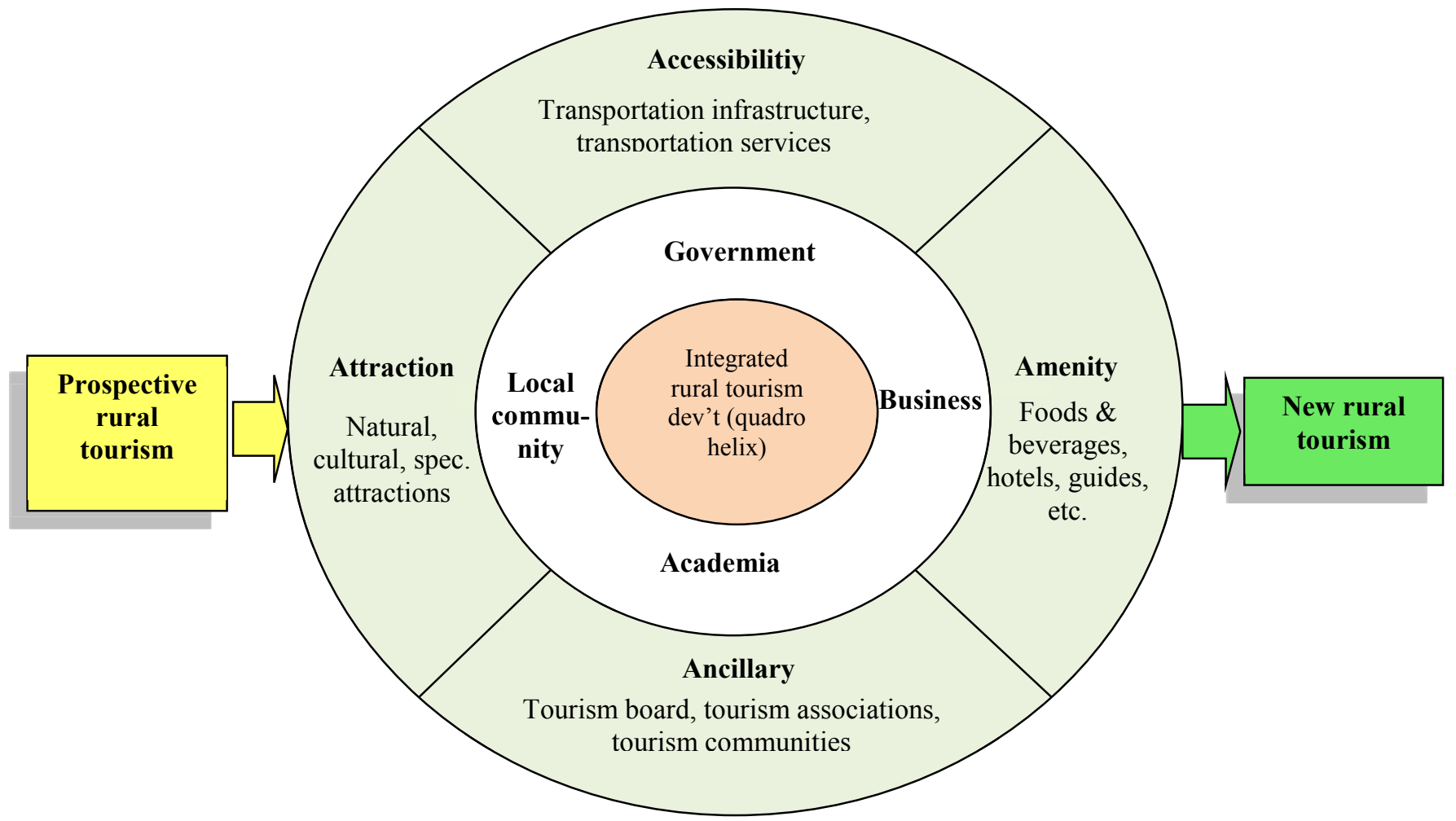

Figure 1. Integrated Rural Tourism Development Model (Sugiama, 2015)

\section{B. Tourism Component}

There are four tourism components that call 4As: Attraction, Accessibility, Amenities, and Ancillary (Cooper, 2000., Sugiama, 2014a., Sugiama, 2013., Sugiama, 2014c). According to Boskovic, there are several main stages which to determine the condition of existing resources and propose measures for their improvements (Boskovic et al., 2013, p.103).
Tourism as a business system includes a variety of tourism services. Can be categorized as a tourism industry, the tourism industry means covering a wide range of service sectors, and each sector includes a range of business items. Among tourism service sector includes transportation, accommodation, and tourist attractions. A tourist accommodation services sector in which includes a number of different services such as 
accommodation services, food, and drinks for tourists. For the benefit of the services offered lodging hotels, motels, homestay, guesthouse, and others. As for the food and drinks, there are several kinds of offers services such as restaurants and catering.

The development of each tourist destination can open up new business field which became the source of another income. There are eight sectors of tourism sector which have been open since the development of the tourism industry in a tourist destination includes Accommodation, Adventure Tourism and Recreation, Attractions, Events and Conferences, Food and Beverage, Tourism Services, Transportation, Travel Trade. As a simple system rural tourism Industry can be grouped into 6 sectors as Figure 2:

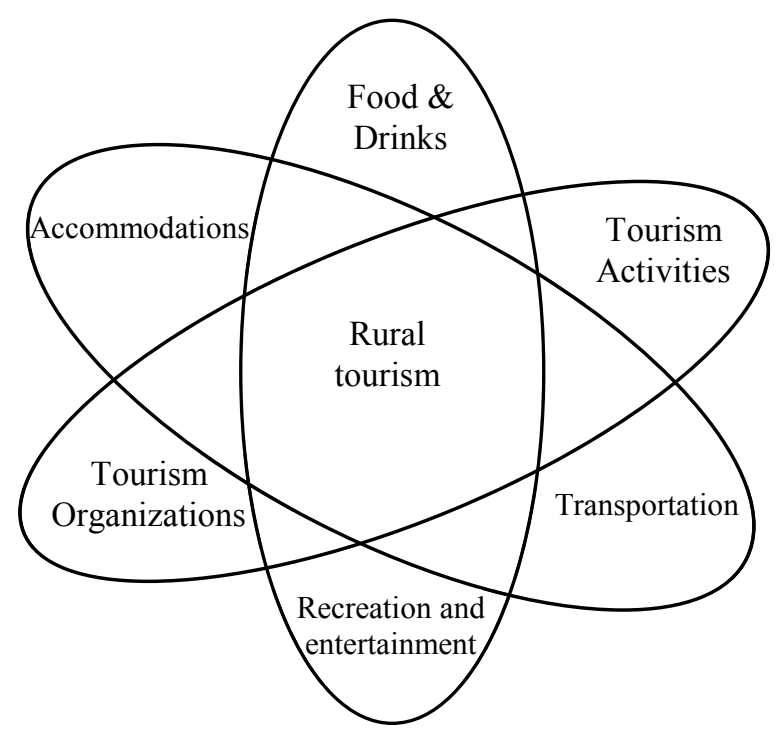

Figure 3. Six Sectors in Tourism Industries (Sugiama ${ }^{\mathrm{c}}$, 2011)

In this Figure there are six different Industry need to be provided in rural tourism area. Each of Industry needs support from the Tourism Organizations.

The rural tourism development is based on the concept of sustainability, which integrates environmental, economic, political, cultural and social considerations (Dragulanescu and Maricica, 2012, p.201); there is a recognition that to be sustainable, the preservation of the natural environment must be grounded in the communities and societies, which exploit and depend upon it (Richards and Hall, 2000). Both rural development and planning are at the confluence of urban areas expansion, the aggressive development of rural industry and the requirement due to possible areas to maintain its current size (Dragulanescu and Maricica, 2012, p.196).

The efforts in order to strengthen the economic development of rural areas are comprehensive, given the largeness of its tourist value, viewed from economically, environmentally, socially and culturally (Dragulanescu and Maricica, 2012, p.196). As Pejanovic's research result indicates, it is undisputed that the Municipality of Bački Petrovac has quality predisposition for the development of different forms of tourism, however without a clear vision of sustainable development and cooperation with the local population, tourism will not be among the holders of economic development (Pejanovic et al., 2014, p.498). The concept of sustainable tourism, where rural tourism is very well defined, covers preserving the natural environment, traditions, customs, culture, and the satisfaction or fulfillment for the tourist town full of sophisticated services and hotels (Dragulanescu and Maricica, 2012, p.196), they are called as 4As rural tourism components: Attraction, Accessibility, Amenity, Ancillary (Cooper, 2000., Sugiama, 2014c).

\section{RESEARCH METHOD}

This research focus on exploratory study with the descriptive qualitative method, which means that the data collected by qualitative and exploration and then describe in descriptive analysis. The data was gathered by observation in the Selasari Village as rural tourism area and in-depth interview to the head of the Village as local Government and the rural communities as a developer. Questionnaire for interview and checklist was used to gather the data with judgment sampling technique guided.

The primary data collected through observation and interview in surroundings area. There were also secondary data as supporting to ensure the primary data. Also, the researcher also experiences the tourism activities such as body rafting and walking through some tourist attraction in the rural tourism area to gain personal perspective and judgment.

\section{RESULTS AND DISCUSSION}

\section{A. General Information about Selasari Rural Tourism Area.}

Selasari village located in the district of Pangandaran, which are located right on the coastal area of Pangandaran district. Selasari village is one of the seven villages in the district of Parigi, Pangandaran Regency. Here's the general data of Selasari Village (Selasari,2015):

- Name of the village : Selasari

- Sub District : Parigi

- District of : Pangadaran

- Province : West Java

- Total area : : 1,935 ha.

- Altitude :300m above sea level.

- Special conditions: karst stones in some territories

There are more than 90 natural caves, Natural mountainous coastal regions. Tourism services facilities are still limited. Some cave and river in the village of Selasari have become a tourist spot, but the number of tourist arrivals and management is still limited. Based on the identification of Tourism component in the village, it has the potential to be used as rural tourism area. In this occasion, the following data is presented on the characteristics of Selasari village. 


\section{B. Quality of $4 A$ 's Tourism Component}

\section{Attraction.}

The results show that there are 3 type of potential tourist activities in Selasari, not only explore the natural activities but also cultural and special interest tourism. Selasari has 8 caves, 3 Rivers, beautiful Mountain views, and also conservation Forrest that potential to be developed in the future. 5 of the caves can be explored through the river that passes inside the caves, and 3 of the caves can only be explored by walk inside it. Selasari also had traditional dances and ceremonies that can be developed as cultural tourism. All of the three Rivers only can be explore by doing special interest tourism activities such as body rafting, and jump cliff in the end of each river.

These tables show the Tourist attraction that potential to be develop based on Natural, Culture, and special interest point,

Tabel 1. Tourist attraction in Selasari

\begin{tabular}{|c|c|c|}
\hline Natural attraction & Cultural Attraction & $\begin{array}{l}\text { Special interest } \\
\text { attraction }\end{array}$ \\
\hline $\begin{array}{l}\text { 1. Caves: } \\
\text { - Goa Sutra } \\
\text { Reregan, } \\
\text { - Goa Panggung, } \\
\text { - Goa Peteng, } \\
\text { - Goa Panjang, } \\
\text { - Goa Parat, } \\
\text { - Goa Lanang, } \\
\text { - Goa Gede and } \\
\text { - Goa Citalun. } \\
\text { 2. Mountain } \\
\text { views, } \\
\text { 3. River rafting } \\
\text { activities, } \\
\text { 4. Waterfall and } \\
\text { 5. Conservation } \\
\text { forest. }\end{array}$ & $\begin{array}{l}\text { Site : } \\
\text { - } \quad \text { Kampung } \\
\quad \text { Buhun, } \\
\text { - } \quad \text { Tapak ki } \\
\quad \text { Jonggrang, } \\
\text { - Tapak Budha, } \\
\text { - } \quad \text { Batu Putih } \\
\quad \text { (Batu Bagong) } \\
\text { - Eyang Gede } \\
\text { - Mbah } \\
\quad \text { Jagaraksa } \\
\text { - } \quad \text { Sundanese Art }\end{array}$ & $\begin{array}{l}\text { 1. Body } \\
\text { Rafting or } \\
\text { Water } \\
\text { Tubing } \\
\text { 2. Climbing } \\
\text { 3. Cross } \\
\text { country } \\
\text { 4. Four wheel } \\
\text { Off Road } \\
\text { 5. Motor Trail } \\
\text { 6. Mountain } \\
\text { bike }\end{array}$ \\
\hline
\end{tabular}

\section{Accessibility.}

The aspect of accessibility in the rural tourism of Selasari Village is not quite good. Although the location of Tourist village away from the town of Pangandaran, it turns out that Tourist still has the desire to visit it, due to the fact that they have a unique attraction. Usually, sometimes Tourist were frustrated about the bad condition of the road as became the main factor that the accessibility is not as good as they expected. After a survey it turns out also that not enough sign boards how to get to there, sometimes Tourist need to ask many times just to make sure they were on the right way.

\section{Amenities.}

The availability of services for accommodation in the form of lodging, food and drinks for tourists in the Selasari still limited. An area of rural tourism can be categorized as Tourism Village if it meets service that allows travelers to stay for 24 hours with a safe and comfortable conditions. Based on current conditions, Selasari Villages still did not have a good standard quality of Accommodations regarding the quality of rural tourism area. The only have some local house to rent near the villages office. Regarding foods and drinks Selasari have a lot of shop and store to sell, but still not enough in the peak season. Its facilities such as chair and table also not good enough. However, Some of Tourist also expected that all food and beverages, accommodation (homestay), and toilets maintained in terms of cleanliness and health. Another thing about the price of food and beverages is too high for local Tourist. It need also adequate by the travelers in the mid segment.

\section{Ancillary.}

Tourism activities in Selasari still not managed professionally. The local Government of the village and Tourist attraction Management (Karang Taruna) still not had a formal organization with a permanent organizational structure. The perpetrator or dominant operator is the youth of the local it called "Karang Taruna". The concern of this Organization still how to Guide Tourist in Santirah body rafting activities. Local Government of Selasari planned to have their own Organizations in each of Attraction and Tourist expected it being run by a professional manager or Organization. Various information regarding the relevant tourist village needs to be presented on the internet to give information to tourists such as how to get there and activities the Traveler can have in there. Based on secondary data from Internet and social media the Traveler also expected that they can make a reservation through the Internet or telephone (online) or get some information about the packages offered while the stay in there.

\section{Potential Tourism Component that can be developed. 1) Attraction}

The quality of the components expected to have better aspects in the future as follows:

1. Panorama of Mountains and river views rural nature preserved

2. Restricted rules and norms to maintain the attraction keep clean and does not have negative impact by the Tourist who came

3. Local traditional culture as an additional attraction for tourists who visits there

4. Rural area life hood such as the procedure of local farming in the countryside can be a tourist attraction for tourists

5. Unique food and drink that sold not too expensive in rural tourism area to be presented for tourists

6. Attitude, hospitality as one of the unique and typical habits in rural communities need to be maintained so travelers can be happy stay for long in there. 


\section{2) Accessibility}

Accessibility has a very important role as a major component of tourism (Sugiama, 2013). Based on the data there are several point of views and aspects that can be developed in the future:

1. Tourist villages do not need close to a town. This means that although tourist village that is quite far away from town if they have an interesting view, travelers will come as long as

2. Adequate road infrastructure to pass by four-wheeled vehicles

3. Tourist village does not have to be too close to the highway

4. recreation place tourist village spread can be reached quite through the path

5. A tourist village would be better if it provides local transportation that easy to get from or to the area.

6. Completeness signpost towards nearest town and in a location that can help tourist to have the direction how to get to the location and it should be constructed informatively.

\section{3) Amenities}

Amenities include the provision of accommodation services, food, and beverages are a major component in the rural tourism area. The adequate facilities can make tourist stay longer than before (minimum 24 hours) stay in the area. Some of the point that can be developed in the Selasari Rural area, such as:

1. Clean and healthy Restaurant or local shops is the minimum standard for tourist.

2. Providing minimum standard for clean and healthy Toilet or bathroom in local homes (home stay) and maintain safety 24 hours for tourists

3. Food and drinks provided should be not too expensive, can be reached by middle segments.

4. Local communities of the rural tourism area should keep friendly as usual when the meet the others. This condition can give valuable point which can make Tourist want to stay for a long period because of the local friendliness.

\section{4) Ancillary}

Management requires a tourist village roles of the various parties (stakeholders), especially the local community (host community), local government, industry marketers especially rural tourism area, and from the academia. Here are some of the points that can be developed in the future:

1. Information about everything in the rural tourism area can be obtained easily via the internet or online.

2. Rural Tourism Development expected to be supported highly by the District Government and the local community.

3. The rural tourism or village can be managed by a special organization of professional, different with the local Government.
4. Online Reservation (Internet or phone) such as tour packages (activities, accommodation, and meals) can be done easily.

5. The organizations also provide a professional staff such as tour guide who responsible for rural tourism activities.

\section{CONCLUSIONS AND SUGGESTIONS}

Based on the findings and analysis of the previous section, rural tourism need appropriate $4 \mathrm{~A}$ 's tourism components to be established to adequate the needs of Tourist activities in the area. The rural tourism will be effective to attract tourist stay longer in the area, so gave multiple effects to the local communities. Natural Cultural Conservation should also consider as a basic needs for the sustainability of the tourist attraction. Herewith some of the point view in order to conclude and suggest the development of 4A's Tourism Component in Selasari Rural Tourism.

\section{A. Conclusions}

There is 3 type of potential tourist activities in Selasari, not only explore the natural activities, but also cultural and special interest tourism. Selasari has 8 caves, 3 Rivers, beautiful Mountain views, and also conservation Forrest that potential to be developed in the future. 5 of the caves can be explored the river that passes inside the caves, and 3 of the caves can only be explored by walk inside it. Selasari also had traditional dances and ceremonies that can be developed as cultural tourism. All of the three Rivers only can be explore by doing special interest tourism activities such as body rafting, and jump cliff at the end of each river. According to the data that collected, the other A's still needs to develop in the future especially the accessibility and amenities because these does not meet the tourism component standard such as bad road and out of standard Accommodation or Restaurant. In fact, it is slightly difficult to find these place because not enough sign board from another area in Pangandaran. The last A for Ancillary has been quite good but need additional efforts, such as need support from the local government of Pangandaran, strict rules that could strengthen its presence of the natural especially the forest to keep the water in its places and much more. Selasari rural tourism area potential to be developed heavily in the future, however, the District or Central Government need to support this and concern in order to increase the income of local communities and poverty alleviation.

\section{B. Suggestions}

As mention in Literature Review in the previous section (Figure.1, p.2) Integrated rural tourism development Model should be applied in Selasari Rural Tourism area. The four stakeholders such as Government, Local Communities, Tourism Industry and Academia should work together to achieve all the necessary tourism component such as attraction, accessibility, amenities and ancillary establish in Selasari Village. Without the coordination and synergy from all the stakeholder, it will be so hard to fulfill the adequate 4A's Tourism Component. 
Herewith the detail of suggestion of all 4A's Tourism Component that needs to develop.

\section{1) Attraction}

Local Government and or Organization who runs the tourist attraction should identify and maintain the conservation of natural and cultural attraction, so the special interest tourism activities still available to do in Selasari for a longer period. Regarding managing the Tourist attraction, the Management should pay attention to

1. Conservation of natural and cultural such as forest and rivers.

2. Maintain Local traditional culture and rural livelihood such as farming which can be an alternative attraction.

3. Preserved traditional food and drinks and always train and maintain good behavior or tourism services attitude of the local people to the welcoming tourist who visit.

\section{2) Accessibility}

District Government cooperates with central Government of West Java Province should help local Government of Kertayasa region to improve the quality of the road so Tourist will be easy visit the rural area in Pangandaran. This is one of priority action in the development of this rural tourism area. Except fixing the road, the management also needs to provide some basic infrastructure such as local transportation and create a walking path and also Completeness signpost to or from the Village.

\section{3) Amenities}

For a short period, the Management should improve the quality of Toilet and maintain the cleanliness and healthiness of the Accommodations and restaurant. Providing security aspect in 24 hours to make tourist feels comfort stay in the Village. In long period, the Management should provide,

1. Adequate, Clean and Healthy Restaurant or local shops in the Village

2. Create rules that manage prices that offered by seller so the food or drinks would not sell too expensive

3. Maintain the local uniqueness and also traditional architecture of the new amenities' building, so the concept of rural tourism still can be preserved.

\section{4) Ancillary}

In short period formal Organization should be created and get fully support from the local government of the Village and District Government of Pangndaran. Subsequently, the formal organization should create restricted rules and norms to maintain the attraction keep clean preserved the negative impact and synergy with the other stakeholders. In long Period the local Government of Selasari should invite potential Investor that can help to build facilities or other tourism component in the Tourist Attraction, however the Investor should maintain and manage well to preserve the rural tourism area. There will be so nice also if the local Communities can also establish a formal company that can manage and runs by the local people so the amount of money that generate income can be spread out also to the communities of Selasari Village.
By this, it means that local residents that not related to the rural tourism will also feel the positive impact to help to maintain all the necessaries component in the rural tourism area.

\section{Acknowledgment}

This article is initial study materials which become part of the national strategic research theme of poverty alleviation study that implemented in three years and had been funded by the Indonesian Minister of Education in 2013 to 2015. This study as a whole seeks to discover the marketing integration strategy to increase tourist arrivals and income of the rural poor in Indonesia.

\section{References}

Adamowicz, Joanna (2010), Towards Synergy Between Tourism and Nature Conservation. The Challenge for the Rural Regions: the Case of Drawskie Lake District, Poland, Versita, Europ. Countrys; Vol. 3· 2010; p. 118131.

Anand, Anupam., Pankaj Chandan, and Ram Babu Singh, (2012), Homestays at Korzok: Supplementing Rural Livelihoods and Supporting Green Tourism in the Indian Himalayas, Mountain Research and Development Journal, Vol. 32., No. 2., p. 126-136.

Boskovic, Tatjana., Radovan Tomic., Danilo Tomic (2013), Potentials And Limitations For The Development Of Rural Tourism In Vojvodina., Economics of Agriculture, Vol 60., No. 1., p. 103-113

Cooper, Chris Cs., (2000), Tourism: Principles and Practice, Second Edition, Longman, England

Dorobuntu, Maria Roxana., Gheorghe, Georgica; Nistoreanu, Puiu (2012)., Competitiveness of Agro-Food and Environmental Economy., Conference Papers \& Proceedings., Faculty of Agro - Food and Environmental Economics - Bucharest University of Economic Studies., p. $385-394$

Dragulanescu, Irina-Virginia and Maricica Drutu (2012), Rural Tourism for Local Economic Development, International Journal of Academic Research in Accounting, Finance and Management Sciences., Volume 2, Special Issue 1, pp. 196-203

Esmailzade, Aliakbar, (2013), Factor Analysis of Rural Tourism Development from Villagers Viewpoint in Chaharmahalva Bakhtiari Province (Case study: Yancheshmeh Village), International Journal of Agriculture and Crop Sciences, Vol. 5., Num 21., pp. 26302633

Guo, Jumping., Bin Zhang, and Xiyan Zhang, (2014), Study of Rural Reduction Effect to Traffic Infrastructure, Asian Agricultural Research, Vol 6., Num. 7., p. 4-8 
Ivolga, Anna and Vasily Erokhin (2013), Tourism as an Approach to Sustainable Rural Development: Case of Southern Russia, Economic of Agriculture, Vol. 60, No. 4, p.789-800

Karmilah, Mila, Wiendu Nuryanti., Nindyo Soewarno., Bakti Setiawan., (2014), Community Involvement in Tourism Development: As Strategy for Poverty Alleviation after the earthquake (Case Study: Kasongan Village Yogyakarta), International Journal of Scientific and Research Publications, Volume 4, Issue 12, pp. 1-7.

Lietaer, Bernard and Stephen De Meulenaere, (2003), Sustaining Cultural Vitality in a Globalizing World: the Balinese Example, International Journal of Social Economics, Vol. 30 No. 9, 2003, pp. 967-984

Matiza, Tafadwa and Olabanji A Oni (2014), The Perceived Economic Benefits of Tourism: The Case of a Rural Community Bordering the Kruger National Park in Limpopo Province, South Africa, Mediterranean Journal of Sciences, Vol 5. No. 20, p.322-328

Mrkša, Milutin \& Tamara Gajić (2014), Opportunities for Sustainable Development of Rural Tourism in the Municipality of Vrbas, Economics of Agriculture, Vol. (61) 1, pp. 163-175

Mutana, Sarudazai (2013), Rural tourism for pro-poor development in Zimbabwean rural communities: Prospects in Binga rural district along Lake Kariba. International Journal of Advanced Research in Management and Social Sciences, 2(4), 147-164.

Pejanovic, Radovan., Dunja Demirovic., Jasmina Dordevic and Gordana Radovic, (2014), Potentials for Development of Rural Tourism in Bački Petrovac Municipality, Journal of Economics of Agriculture, Vol. 1-22., pp.487-500.

Richards G., Hall D., (2000), Tourism and Sustainable Community Development, Routledge, New York.

Sugiama, A Gima., Jann Hidajat, dan Tomy Adrianto, (2014b), The Integrated Marketing Strategy to Increase Tourist Visit and Income of Poverty in the Rural Area (Strategi Integrasi Pemasaran Desawisata untuk Meningkatkan Kunjungan Wisatawan dan Pendapatan Masyarakat Miskin Pedesaan), Research Report of The Strategic National Research in Indonesia, Bandung State Polytechnic
Sugiama, A Gima (2013), Tourism Asset Management:The Effect of Service Quality on Tourist Satisfaction and Loyalty (Manajemen Aset Kepariwisataan: Pelayanan Berkualitas agar Wisatawan Puas dan Loyal), Edisi 1, Guardaya Intimarta, Bandung.

Sugiama, A Gima., Jann Hidajat, dan Tomy Adrianto, (2015), The Integrated Marketing Strategy to Increase Tourist Visit and Income of Poverty in the Rural Area (Strategi Integrasi Pemasaran Desawisata untuk Meningkatkan Kunjungan Wisatawan dan Pendapatan Masyarakat Miskin Pedesaan agar wisatawan puas dan loyal), Research Report of The Strategic National Research in Indonesia, Bandung State Polytechnic

Sugiama, A Gima dan Santosa Sanjaya, (2011), Model Pengembangan Aset Wisata Agro yang Berkontribusi pada Potensi Perluasan Keragaman Usaha dan Pedapatan Petani (Kasus dan Perancangan Wisata di Kawasan Pertanian Hortikultura Cikajang Garut), Laporan Penelitian, UPPM-Polban, Bandung

Sugiama, A Gima (2014c), The Framework of Rural Tourism Development, Business and Economic Seminar, Proceeding, Jenderal A Yani University, Bandung, ISSN2406-8942., pp. 404-410.

Sugiama, A Gima (2009), Ecotourism: Tourism Development Based on Natural Conservation, First ed., Guardaya intimarta, Bandung

Walpole, Matthew J and Harold J Goodwin (2001), Local attitudes towards conservation and tourism around Komodo National Park, Indonesia, Environmental Conservation, Foundation for Environmental Conservation, Vol. 28, No. 2., p. 160-166.

\section{Other References}

Desa Selasari (2015), Kantor Desa Selasari, Access 30 Juni 2015, sources: http://selasari.desa.id/

Desa Selasari (2015). Informasi wisata, access 01 January 2016, sources: http://desawisata-selasari.com

Kompas.com. (2015), Ini UKM Jawa barat Tahun 2015, Access 30 Juni 2015, sources: http://regional.kompas.com/read/2014/11/22/07020041/ ini.UMK.Jawa. Barat.2015 